\title{
Implications of total content of silicon, aluminium, chromium and formation of thin ferrite films on low ductility at high temperature in non oriented electrical steels ${ }^{(\bullet)}$
}

\author{
F. Equihua-Guillén*, R. Servín*, J. R. Muzquiz-Riojas*, J. E. Camporedondo-Saucedo** and M. Aguilar-González***
}

\begin{abstract}
This work shows evidence of the implications of total additions of silicon, aluminium and chromium on low ductility during hot rolling in non-oriented electrical steels. This paper explains the reason of ductility loss at temperatures between $950-1000^{\circ} \mathrm{C}$ in electrical steels which exhibit higher $\mathrm{Ar}_{3}$ transformation temperature than $\mathrm{C}-\mathrm{Mn}$ and microalloyed steels. The empirical equations to determine $\mathrm{Ar}_{3}$ temperature do not consider silicon and aluminium elements. The results show that high content of silicon, aluminium and residual concentration of chromiun considerably increases $\mathrm{Ar}_{3}$ transformation temperature in non-oriented electrical steels. The low ductility at high temperature occurs between $\mathrm{Ae}_{3}$ and $\mathrm{Ar}_{3}$ transformation temperatures. In addition, the results of this work show evidence of thin ferrite films formed near $\mathrm{Ar}_{3}$ temperature and their implications on ductility loss at high temperature.
\end{abstract}

Keywords

Electrical steel; Ductility loss; $\mathrm{Ar}_{3}$ temperature; Intergranular crack.

\section{Implicaciones del contenido total de silicio, aluminio, cromo y formación de películas delgadas de ferrita sobre la baja ductilidad a alta temperatura en aceros eléctricos no orientados}

\begin{abstract}
Resumen
Este trabajo muestra evidencia de las implicaciones de la cantidad total de silicio, aluminio y cromo sobre la baja ductilidad en aceros eléctricos durante la laminación en caliente. Este artículo explica la razón de la pérdida de ductilidad a temperaturas entre 950 y $1.000^{\circ} \mathrm{C}$ en aceros eléctricos. Las ecuaciones empíricas para determinar la temperatura $\mathrm{Ar}_{3}$ no consideran los elementos aluminio y silicio. Los resultados muestran que altos contenidos de silicio, aluminio y la concentración residual de cromo incrementan considerablemente la temperatura de transformación $\mathrm{Ar}_{3}$ en aceros eléctricos de grano no orientado. La baja ductilidad a elevada temperatura ocurre entre las temperaturas de transformación $\mathrm{Ae}_{3}$ y $\mathrm{Ar}_{3}$. Adicionalmente, los resultados de este trabajo muestran evidencia de películas delgadas de ferrita formadas a temperaturas cercanas a $\operatorname{Ar}_{3}$ y sus implicaciones sobre la pérdida de ductilidad a alta temperatura.
\end{abstract}

Palabras clave Acero eléctrico; Baja ductilidad; Temperatura $\mathrm{Ar}_{3}$; Fractura intergranular.

\section{INTRODUCTION}

The ductility loss at high temperature in steels has been widely investigated due to the requirement to avoid intergranular cracking in slabs and strips produced by continuous casting and hot rolling, respectively ${ }^{[1-15]}$. That phenomenon has been associated to microstructural changes which promote several crack mechanisms: restriction of the interface mobility of austenite grain

(·) Trabajo recibido el día 02 de Febrero de 2011 y aceptado en su forma final el día 21 de Marzo de 2011.

* Facultad de Ingeniería Mecánica y Electrónica. Universidad Autónoma de Coahuila. Av. Barranquilla S/N, Colonia Guadalupe. C.P. 25750, E-mail: fabianequihua@gmail.com,rumualdo.servin@aceroteca.com,ji_muzquiz@hotmail.com.

** Facultad de Metalurgia. Universidad Autónoma de Coahuila. Carretera 57 Km. 5 Monclova, Coahuila. C.P. 25710, E-mail: emiliocamporedondo@uadc.edu.mx.

*** Centro de Investigación y de Estudios Avanzados del Instituto Politécnico Nacional Unidad Saltillo. Carretera Saltillo-Monterrey Km. 13. Molinos de Rey. C.P. 25900 P.O. Box 663, Saltillo Coah, México E-mail: mgzlz@hotmail.com 
boundaries ${ }^{[16]}$, formation of precipitates free zone (PFZ's) ${ }^{[17]}$, formation of strain-induced ferrite films ${ }^{[18-32]}$ and the formation of inclusion and precipitates at austenite grain boundaries. These mechanisms can act simultaneously depending on temperature, deformation rate, chemical composition and thermo-mechanical history of the steel.

García et. al. ${ }^{[33]}$ estimated low ductility at temperatures between $950-1000^{\circ} \mathrm{C}$ in grain non oriented electrical steels. In this case, the tensile crack mechanism involves coalescence of microvoids nucleated on AlN particles and phases of silicon. Although, it is common in C-Mn and microalloyed steels this behavior, the loss of ductility, in many steels, occurs at lower temperatures than the abnormal high temperatures observed in electrical steels. On the other hand, high content of residual chromium also contributes to increase $\mathrm{Ar}_{3}$ temperature.

Ductility loss in hot rolled C-Mn and microalloyed steels has been associated to simultaneous presence of intergranular thin films of proeutectoid ferrite $(5-20 \mu \mathrm{m})^{[34-37]}$ and nitrides particles or carbides precipitated at the austenite or ferrite grain boundaries. It has been demonstrated that ferrite films can be formed strain-induced at high temperatures such as $\mathrm{Ae}_{3}$ (equilibrium temperature) but, generally, they are formed close to $\mathrm{Ar}_{3}$ temperatures (austenite ferrite transformation temperature on cooling at finite rates). Yada et. al. ${ }^{[38]}$ reported that ferrite was formed during the deformation, even above $\mathrm{Ae}_{3}$, with para-equilibrium, which was analyzed by in-situ X-ray diffraction method. Furthermore, no evidence of formation of ferrite films at austenite grain boundaries was presented in prior work for electrical steels ${ }^{[33]}$.

Tamura et al..$^{[39]}$ developed regression equations for controlled rolled steel by relating chemical composition and thickness of the plates with $\mathrm{Ar}_{3}$ temperature. The validity range of the equation is for carbon content between 0.03-0.16 wt \%. However, the equation does not contain any term for silicon and aluminium, which increases the $\mathrm{Ar}_{3}$ temperature. The equation reads as follows:

$$
\begin{aligned}
& \mathrm{Ar}_{3}=910-310(\% \mathrm{C})-80(\% \mathrm{Mn})-20(\% \mathrm{Cu}) \\
& -15(\% \mathrm{Cr})-55(\% \mathrm{Ni})-80(\% \mathrm{Mo})
\end{aligned}
$$

The predicted temperatures by Eq. 1 result about $830-840^{\circ} \mathrm{C}$. Notably, it predicts lower temperatures than the observed at low ductility values in \% RA curves for electrical steels ${ }^{[33]}$.
Thus, the aim of this work was to determine the start and end temperatures of austenite decomposition on cooling conditions at temperatures near $\mathrm{Ae}_{3}$. Particularly, it was considered the effect of chemical composition $\left(\mathrm{Si}+\mathrm{Al}+\mathrm{Cr}\right.$, wt \%) on $\mathrm{Ar}_{3}$ temperature of the experimental steels.

The presence of nitrides and AlN particles in electrical steels, alloyed with silicon and aluminium, is imperative due to high contents of silicon and aluminium. Nevertheless, other condition that can cause low ductility at high temperature is the formation of proeutectoid thin ferrite films surrounding austenite grain boundaries. Thus the importance of the results of this work is to reduce the intergranular crack during hot rolling of electrical steels.

\section{EXPERIMENTAL}

Six $3.5 \mathrm{~mm}$ thick hot rolled low carbon, Si-Al electrical steel strips were obtained from a local supplier. Chemical analysis was performed by optical emission spectrometry and the LECO combustion technique for carbon and sulphur. The chemical compositions of the strips are listed in table I.

Samples, $9 \mathrm{~mm}$ wide and $15 \mathrm{~mm}$ long, were cut from the strips and reduced to $0.8 \mathrm{~mm}$ thick. The samples were grounded on progressively finer $\mathrm{SiC}$ abrasive papers up to a final thickness of $0.3 \mathrm{~mm}$. Finally, the samples were polished to a metallographic quality specular finish using diamond paste. The detection of $\mathrm{Ar}_{3}$ transformation temperature was followed by in-situ high temperature X-ray diffraction in an Anton-Paar high temperature chamber adapted to a multipurpose Philips X-ray diffractometer. This system uses a Pt-filament (a $1 \mathrm{~mm}$ thick, $9 \mathrm{~mm}$ wide, $132 \mathrm{~mm}$ long strip) both as heating element and specimen holder. Protection of the Pt-filament and the sample against oxidation was provided by a continuous flow $(1.5 \mathrm{lt} / \mathrm{min})$ of ultra high purity Helium gas in the hot chamber. Measurement and control of the temperature during the experiments were performed within $2^{\circ} \mathrm{C}$ using a $\mathrm{Pt} / \mathrm{Pt}-10 \% \mathrm{Rh}$ thermocouple spot welded to the back of the Pt-filament.

The specimens were heated at a rate of $1{ }^{\circ} \mathrm{C} / \mathrm{s}$ up to $1050^{\circ} \mathrm{C}$ and soaked during $5 \mathrm{~min}$. After that, the samples were first continuously cooled to $1000^{\circ} \mathrm{C}$ at a rate of $-1{ }^{\circ} \mathrm{C} / \mathrm{s}$ and then in a stepwise manner at the same rate with a step size of $10^{\circ} \mathrm{C}$. X-ray diffraction patterns from 
IMPLICATIONS OF TOTAL CONTENT OF SILICON, ALUMINIUM, CHROMIUM AND FORMATION OF THIN FERRITE FILMS ON LOW DUCTILITY AT HIGH TEMPERATURE IN NON ORIENTED ELECTRICAL STEELS IMPLICACIONES DEL CONTENIDO TOTAL DE SILICIO, ALUMINIO, CROMO Y FORMACIÓN DE PELLICULAS DELGADAS DE FERRITA SOBRE LABAJA DUCTLIDAD AALTA TEMPERATURA EN ACEROS ELÉCTRICOS NO ORIENTADOS

Table I. Chemical composition of experimental steels, [wt \%]

Tabla I. Composición química de los aceros experimentales

\begin{tabular}{ccccccccccccc}
\hline Acero & $\mathbf{C}$ & Mn & Si & Al & Mo & Cr & P & S & Ni & Cu & V & Co \\
\hline 1 & 0.052 & 0.581 & 0.625 & 0.257 & 0.0132 & 0.016 & 0.015 & 0.0005 & 0.0431 & 0.123 & 0.0004 & 0.00358 \\
2 & 0.049 & 0.602 & 0.658 & 0.271 & 0.0136 & 0.0163 & 0.0138 & 0.0005 & 0.0456 & 0.136 & 0.0004 & 0.00314 \\
3 & 0.063 & 0.594 & 0.495 & 0.24 & 0.0136 & 0.0231 & 0.015 & 0.0005 & 0.0489 & 0.0936 & 0.0004 & 0.00418 \\
4 & 0.068 & 0.587 & 0.451 & 0.21 & 0.0124 & 0.0224 & 0.015 & 0.0005 & 0.0461 & 0.0863 & 0.0004 & 0.00159 \\
5 & 0.055 & 0.636 & 0.613 & 0.27 & 0.0159 & 0.0232 & 0.0119 & 0.0005 & 0.0504 & 0.139 & 0.0004 & 0.00484 \\
6 & 0.0579 & 0.643 & 0.593 & 0.268 & 0.0161 & 0.0238 & 0.0139 & 0.0005 & 0.0514 & 0.14 & 0.0004 & 0.00455 \\
\hline
\end{tabular}

42 to $45^{\circ} 2 \theta$ ( $180 \mathrm{~s}$ measurement time) were recorded at every temperature step from 1000 to $830^{\circ} \mathrm{C}$. Within this angular range, the $(110)^{\alpha}$ and $(111)^{\gamma}$ diffraction peaks of the ferrite and austenite phases appear at about 44.6 and $43.2^{\circ} 2 \theta$, respectively. $\mathrm{The} \mathrm{Ar}_{3}$ transformation temperatures were detected from the effect of temperature on the intensity of the recorded diffraction peaks.

To study the changes in microstructure produced by the transformation on cooling, a set of samples prepared from steel " 1 " were subjected to isothermal transformation treatments with holding times similar to those applied during the "in-situ" X-ray diffraction experiments. In order to monitor the temperature of the specimens a $\mathrm{K}$-type thermocouple was spot welded at the end of each specimen that had the same dimensions as the specimens for $\mathrm{X}$-ray diffraction. In this case, the samples were heated to $1050{ }^{\circ} \mathrm{C}$ at a rate $7^{\circ} \mathrm{C} / \mathrm{s}$ and soaked during $5 \mathrm{~m}$ in a muffle furnace. After that, a stepwise cooling ramp of $0.15^{\circ} \mathrm{C} / \mathrm{s}$ with holding periods of $180 \mathrm{~s}$ every $10{ }^{\circ} \mathrm{C}$ was set in the furnace. After each temperature step a sample was extracted and quenched into a brine bath at $5{ }^{\circ} \mathrm{C}$. Finally, the quenched samples were prepared for metallographic examination using a reflected light microscope.

\section{RESULTS AND DISCUSSION}

Figure 1 shows the effect of total content of $\mathrm{Si}+\mathrm{Al}+\mathrm{Cr}$ on experimental $\mathrm{Ar}_{3}$ and $\mathrm{Ar}_{1}$ temperatures. As can be seen, $\mathrm{Ar}_{3}$ linearly increases with increasing the content of those elements whereas $\mathrm{Ar}_{1}$ remains approximately constant. In the same figure have been included the start and end temperatures of austenite-ferrite transformation obtained from $\mathrm{Fe}$-Si binary phase diagram for contents of C: 0.05 and $0.08 \mathrm{wt} \%$, assuming that the effects of aluminium and chromium are equal and additive to the effect of silicon. As can be appreciated, the experimental $\mathrm{Ar}_{3}$ temperatures are $2-3 \%$ higher than those predicted by Fe-Si diagram, whereas the $\mathrm{Ar}_{1}$ temperatures are $\sim 15 \%$ overestimated. In figure 1 a) $\mathrm{Ar}_{3}$ was calculated by the empirical, equation (1). As can be seen, this equation considers the austenite stabilizers only.

Figure 2 shows the effect of $\mathrm{Si}+\mathrm{Al}+\mathrm{Cr}$ contents on start time $\left(t_{0}\right)$, time at which $50 \%$ transformation $\left(t_{50}\right)$ was observed, and end time $\left(t_{f}\right)$ of austenite - ferrite transformation in the experimental steels. As can be appreciated, increasing $\mathrm{Si}+\mathrm{Al}+\mathrm{Cr}$ total content, the start transformation occurs faster and the total time of the transformation slightly increases as a result of $t_{f}$ reduction. Therefore, the increment of start temperature of austenite decomposition causes that the transformation starts faster also.

Figure 3 shows the effect of total content of $\mathrm{Si}+\mathrm{Al}+\mathrm{Cr}$ on transformation rate defined as:

$$
r \infty \frac{1}{t_{50}}
$$

As can be appreciated, the transformation rate of austenite increases with the content of stabilizers of ferrite, and this effect is increased at contents higher than $0.85 \%$. Considering that the mechanism which controls the transformation is the same, regardless the quantity of stabilizers of ferrite, the dependence of transformation rate as a function of the temperature can be expressed by an Arrhenius equation:

$$
\frac{1}{t_{50}} \infty r=A \exp \left(-\frac{Q}{R T_{50}}\right)
$$



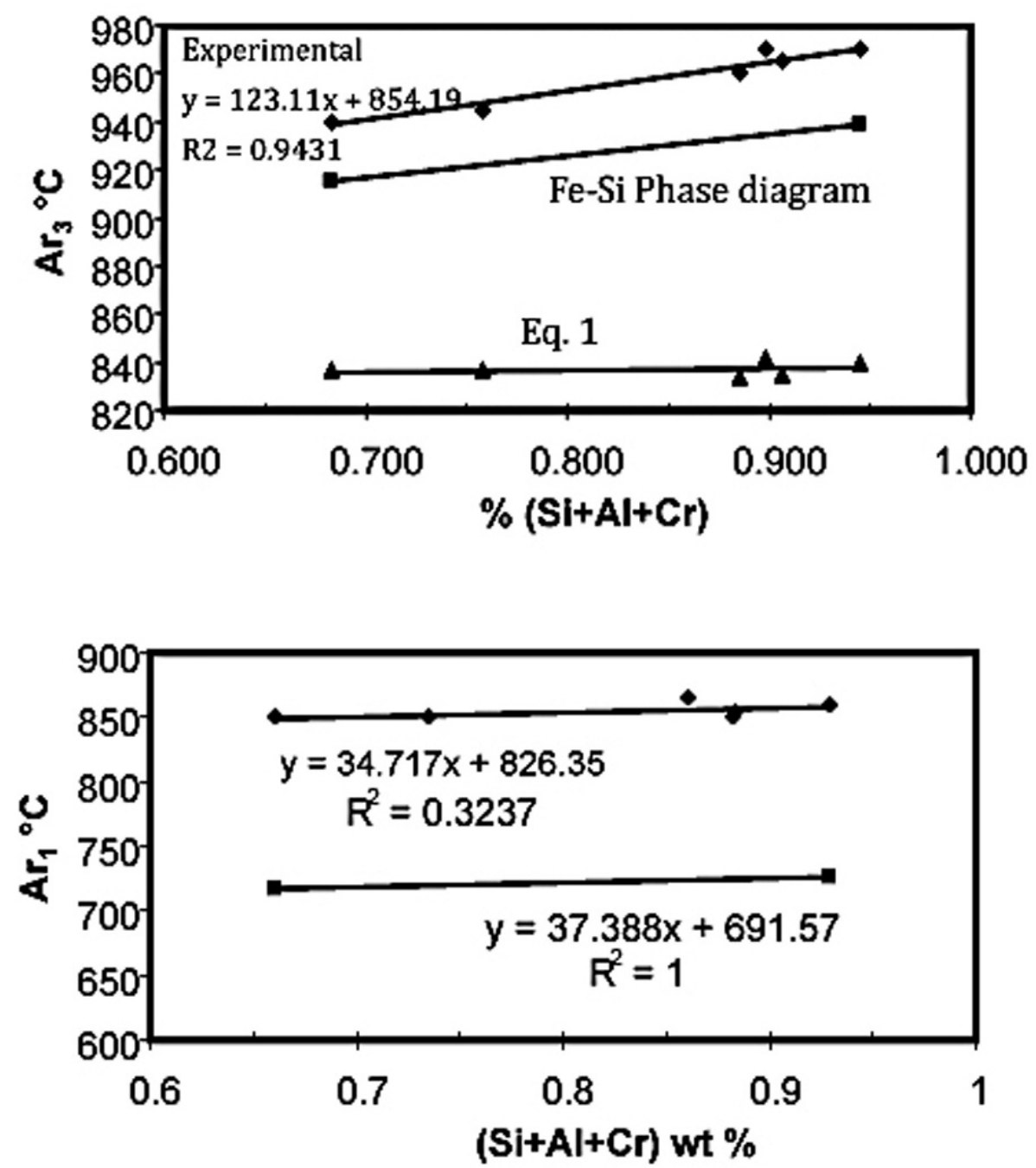

Figure 1. Effect of stabilizers of ferrite $(\mathrm{Si}+\mathrm{Al}+\mathrm{Cr})$ on start $\left(\mathrm{Ar}_{1}\right)$ and end $\left(\mathrm{Ar}_{3}\right)$ temperatures of decomposition of austenite in $\mathrm{Al}-\mathrm{Si}$ GNO electrical steels.

Figura 1. Efecto de los estabilizadores de la ferrita $(\mathrm{Si}+\mathrm{Al}+\mathrm{Cr})$ sobre las temperaturas de inicio $\left(A r_{1}\right)$ y final $\left(A r_{3}\right)$ de la descomposición de la austenita en aceros eléctricos GNO Si-Al.

where $Q$ is the activation energy for austenite ferrite transformation and $\mathrm{T}_{50}$ is the absolute temperature at which $50 \%$ of transformation was observed in the experimental steels. Figure 4 shows the effect of temperature on $1 / t_{50}$. As can be appreciated, the appearance of the curve is identical to that described in figure 3 for effect of ( $\mathrm{Si}-\mathrm{Al}-\mathrm{Cr}$ ) wt $\%$ on $1 / t_{50}$.

From temperature and time for $50 \%$ of transformation, the activation energy of the transformation was calculated $\left(129.15 \mathrm{~kJ}-\mathrm{mol}^{-1}\right)$. As can be seen in figure 5 , the correlation coefficient for the regression of $\ln (\mathrm{r})-1 / \mathrm{T}$ is 0.8 only, which is due to chemical composition differences of the experimental steels, the obtained value of activation energy is $5 \%$ lower than the activation energy required for the diffusion of carbon in austenite $\left(136 \mathrm{KJ}-\mathrm{mol}^{-1}\right)^{[40]}$. Therefore the austenite-ferrite transformation, in the experimental steels, is controlled by diffusion of carbon in austenite. Therefore, the reduction of reaction rate can be explained in terms of reduction of the diffusion coefficient of carbon in austenite when diminishing the temperature.

The shape of allotriomorphic ferrite formed at temperatures close to $\mathrm{Ar}_{3}$ consists of thin films along the grain boundaries of previous austenite with lateral Widmanstätten plates. 


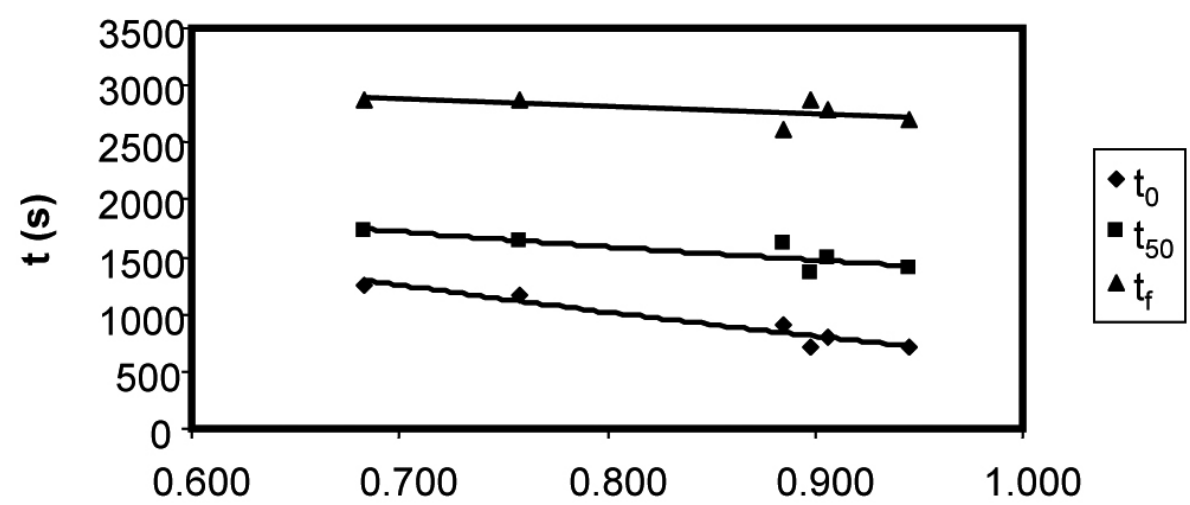

$(\mathrm{Si}+\mathrm{Al}+\mathrm{Cr}) \mathbf{w t} \%$

Figure 2. Effect of total content of $\mathrm{Si}+\mathrm{Al}+\mathrm{Cr}$ on start time (to), at which $50 \%$ of transformation was observed $\left(t_{50}\right)$ and end $\left(t_{f}\right)$ of austenite ferrite transformation in Si-Al GNO electrical steels.

Figura 2. Efecto del contenido total de Si+Al+Cr sobre el tiempo de inicio (to), al cual fue observado el $50 \%$ de la transformación $\left(t_{50}\right)$ y fin $\left(t_{f}\right)$ de la transformación austenita-ferrita en aceros eléctricos GNO Si-Al.

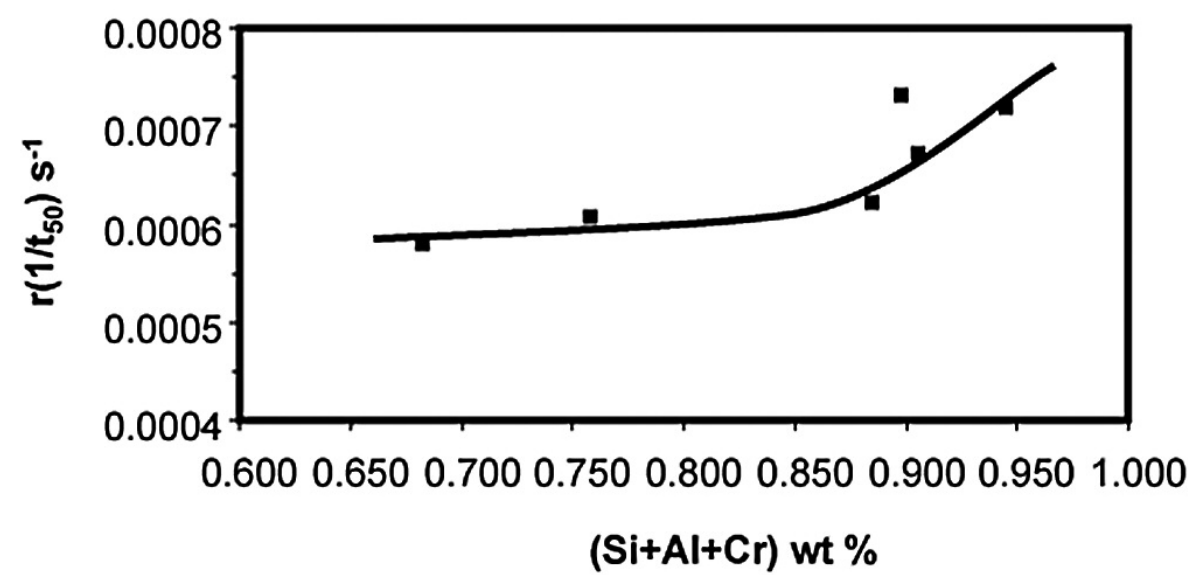

Figure 3. Effect of total content of $\mathrm{Si}+\mathrm{Al}+\mathrm{Cr}$ on transformation rate of austenite in Si-Al GNO electrical steels.

Figura 3. Efecto del contenido total de Si+Al+Cr sobre la velocidad de transformación de la austenita en aceros eléctricos GNO Si-Al.

These phases in the microstructure have important detrimental effects on the ductility loss at high temperature during hot rolling in electrical steels. This process is carried out at temperatures between 1150 and $880{ }^{\circ} \mathrm{C}$. Therefore, and although the steel is rapidly cooled during this process and the temperatures $\mathrm{Ar}_{3}$ and $\mathrm{Ar}_{1}$ at such cooling rates may be inferior to those determined in this work, evidently this kind of materials are partially rolled in the two phase field: austenite + ferrite. The results of this work show that at temperatures close to $\mathrm{Ar}_{3}$, thin films of ferrite along grain boundaries of austenite in a short time ( $1 \mathrm{~s})$ were formed; thin films do not growth considerably up to $180 \mathrm{~s}$ (Fig. 6). Figure 7 shows the thick film of allotriomorphic ferrite as a function of the temperature and time of isothermal heat 


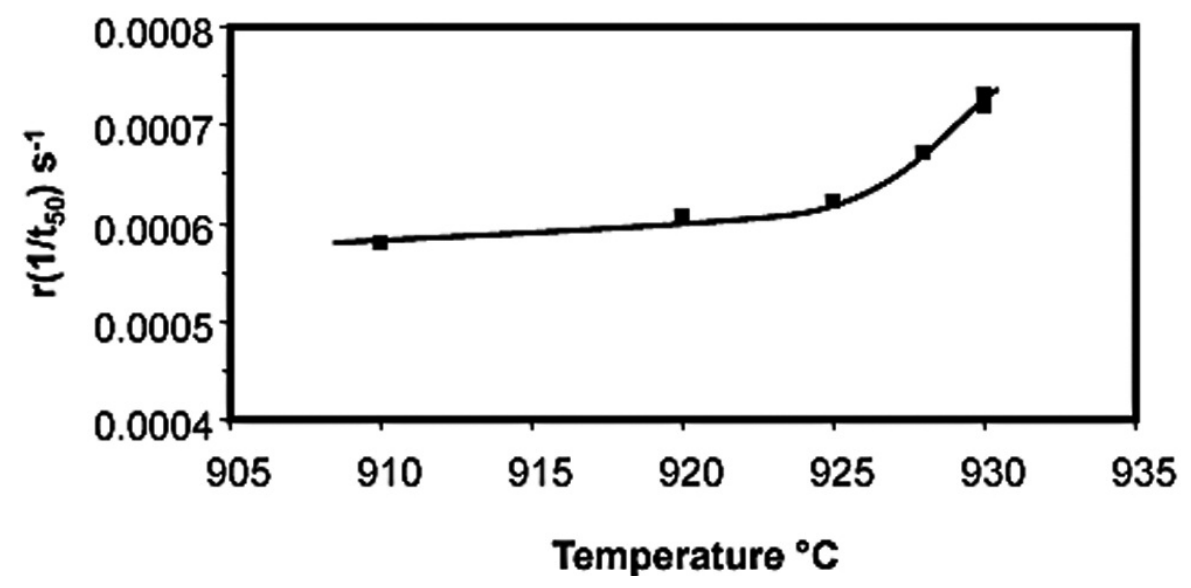

Figure 4. Effect of temperature on austenite-ferrite transformation rate in Si-Al, GNO electrical steels determined by isochronal heat treatments at progressively lower temperatures.

Figura 4 Efecto de la temperatura sobre la velocidad de transformación en aceros eléctricos GNO Si-Al, determinado por tratamientos térmicos isócronos a temperaturas progresivamente más bajas.

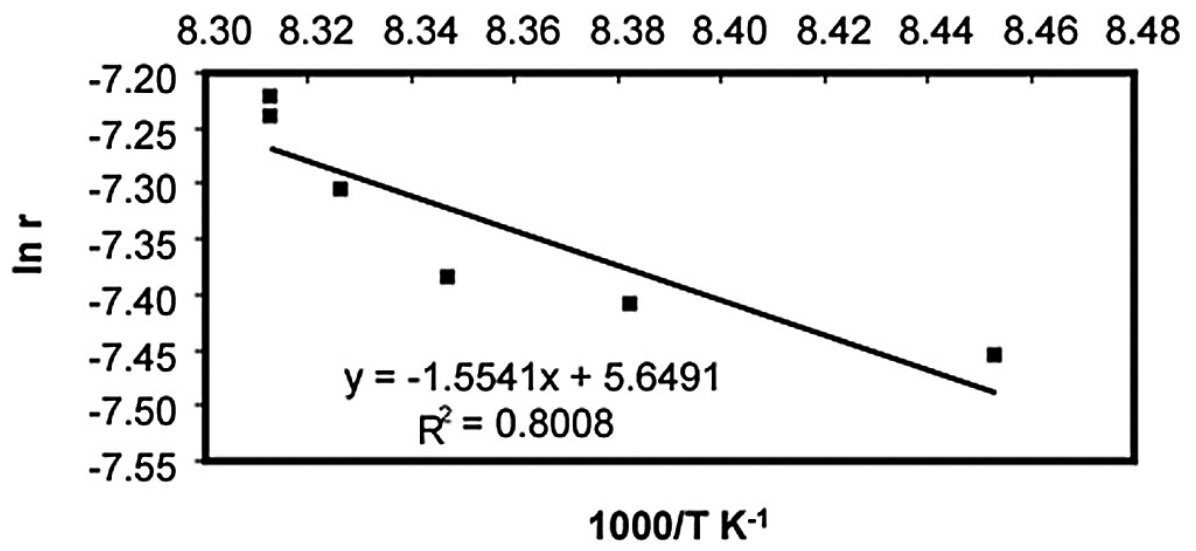

Figure 5. Graph of Arrhenius for austenite decomposition in Si-AI GNO electrical steels.

Figura 5. Grafica de Arrhenius para la descomposición de la austenita en aceros eléctricos GNO Si-Al.

treatment. As can be seen, at temperature between 950 and $970{ }^{\circ} \mathrm{C}$ the thickness of ferrite film is lower than $10 \mu \mathrm{m}$ and it is independent of time of heat treatment. Reed and Bhadeshia ${ }^{[41]}$ have demonstrated that allotriomorphic ferrite growths according to a parabolic law and the growth rate decreases with to increasing thickness due to carbon accumulation at the $\gamma / \alpha$ interface.

Figure 8 shows the microstructures of steel 1 quenched from $900{ }^{\circ} \mathrm{C}$. The recovery of ductility occurs when the thickness of ferrite increases about $20 \mu \mathrm{m}$ near $900^{\circ} \mathrm{C}$, as can be demonstrated by García et. al. ${ }^{[33]}$ in \% reduction area curves.

The ferrite exhibits lower resistance than austenite due to low content of carbon at temperatures in the two phase field. Therefore, ferrite is formed during plastic deformation rapidly and the formation of secondary particles such as nitrides and carbides subsequently take place. These films result in the rapid formation of intergranular cracks by nucleation, growth and coalescence of microcavities mechanisms ${ }^{[42]}$. The electrical steels studied in this work have a 

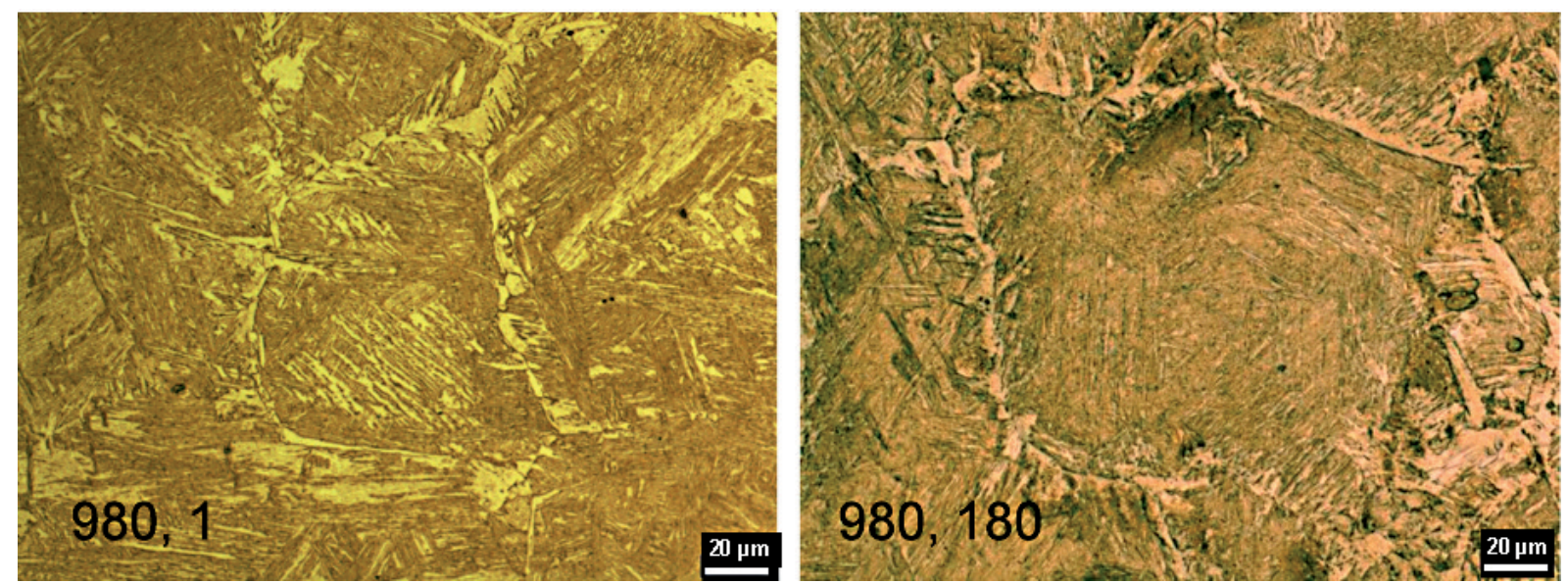

Figure 6. Microstructure at room temperature of Steel 1 austenitized at $1050{ }^{\circ} \mathrm{C}$ during $300 \mathrm{~s}$ an quenched from $980^{\circ} \mathrm{C}$ during: a) $1 \mathrm{~s}$ and b) $180 \mathrm{~s}$.

Figura 6. Microestructura a temperatura ambiente del acero No. 1 austenizado a $1.050{ }^{\circ} \mathrm{C}$ durante 300 s y templado desde $980{ }^{\circ} \mathrm{C}$ durante: a) $1 \mathrm{~s}$ and b) $180 \mathrm{~s}$.

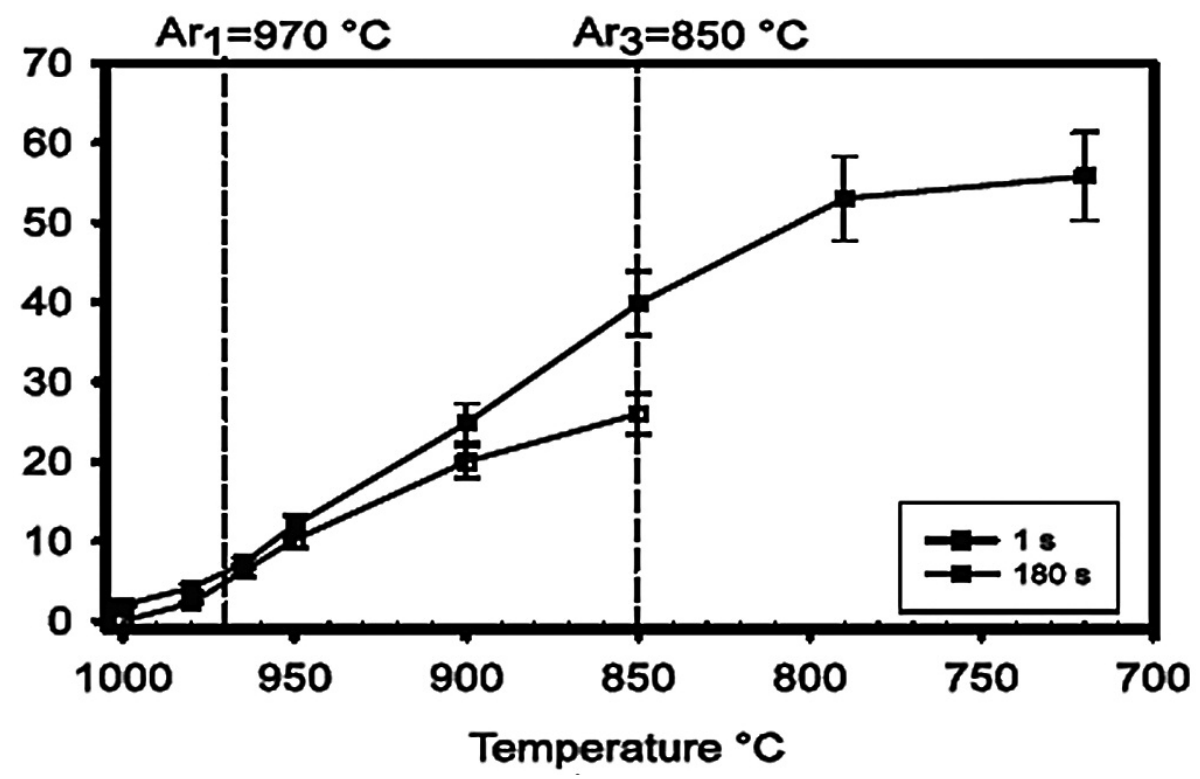

Figure $7 \mathrm{Effect}$ of temperature and time of isothermal heat treatment on thickness of allotriomorphic ferrite in steel 1.

Figura 7. Efecto de la temperatura y tiempo de tratamiento isotérmico sobre el espesor de ferrita alotriomórfica en el acero no. 1.

high content of aluminium and nitrogen. Therefore, they have a high susceptibility to intergranular crack at high temperature compared with low carbon and micro-alloyed steels. As it was mentioned in the introduction, in some similar electrical steels ductility losses at low temperatures $\left(950-1000{ }^{\circ} \mathrm{C}\right)$ have been observed ${ }^{[43]}$. When the deformation temperature increases above $1000^{\circ} \mathrm{C}$ or decreases below $950^{\circ} \mathrm{C}$, high ductility is rapidly recovered.

When the isothermal transformation temperature decreases, at temperature below $850{ }^{\circ} \mathrm{C}$, the microstructure at room temperature does not exhibit ferrite films of proeutectoid ferrite and their morphology change to equiaxial with grain size higher than $50 \mu \mathrm{m}$. 

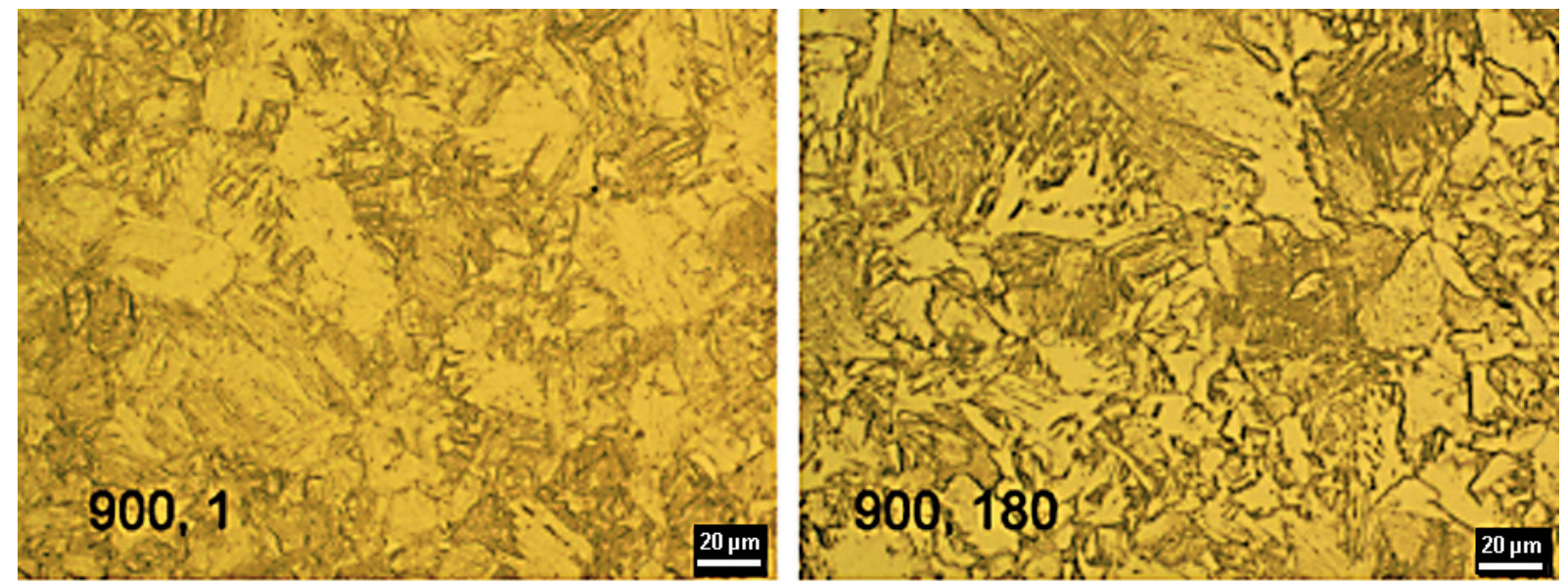

Figure 8. Microstructure at room temperature of steel 1 austenitized at $1050{ }^{\circ} \mathrm{C}$ during $300 \mathrm{~s}$, and quenched from 900 , held during a) $1 \mathrm{~s}$ and b) $180 \mathrm{~s}$.

Figura 8. Microestructura a temperatura ambiente del acero No. 1 austenizado a $1.050^{\circ} \mathrm{C}$ durante $300 \mathrm{~s}$, y templado desde 900, mantenido durante a) 1 s y b) $180 \mathrm{~s}$.

\section{CONCLUSIONS}

- In this work it has been demonstrated that the effect of the temperature and the total content of stabilizers of the ferrite elements on the $\mathrm{Ar}_{3}$ transformation temperature in electrical steels can be estimated by isochronal heat treatments of short duration at progressively lower temperatures by in-situ X-ray diffraction technique. From the estimation of the effect of chemical composition on time and temperature at $50 \%$ transformation, the activation energy for the austenita-ferrite transformation was calculated

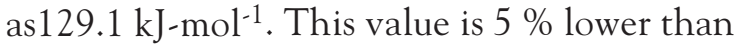
the value of the activation energy for the diffusion of carbon in austenite $\left(136 \mathrm{KJ}^{-} \mathrm{mol}^{-1}\right)$. This mechanism is recognized as the one that controls the decomposition of the austenita during cooling and, therefore, the developed experimental technique was to be adapted for the objectives of the present work.

- The $\mathrm{Ar}_{3}$ transformation temperature, in low carbon, silicon-aluminium electrical steels, depends strongly on the total amount of $\mathrm{Si}+\mathrm{Al}+\mathrm{Cr}$. The data presented in this paper show that both the start temperature of austenite decomposition and the kinetics of the transformation increase with increasing the total amount $\mathrm{Si}+\mathrm{Al}+\mathrm{Cr}$ in the electrical steels. Thus, these elements have a synergistic effect on the transformation. The results show higher $\mathrm{Ar}_{3}$ temperatures than the predicted by the empirical equations and ironsilicon phase diagram. The formation of thin ferrite films surrounding austenite grain boundaries near $\mathrm{Ae}_{3}$ amply explains the low ductility observed in these steels. The data also suggests that formation of thin grain boundary ferrite films prior or during deformation at temperatures near $\mathrm{Ae}_{3}$ may explain the ductility loss observed in these steels at temperatures around $950-1050^{\circ} \mathrm{C}$ by a similar mechanism to that observed in plain carbonmanganese steels. The resulting ferrite of austenite decomposition at temperatures in the $\mathrm{Ar}_{3}-\mathrm{Ar}_{1}$ rank, acquires morphology of films formed on prior austenite grain boundaries. The thickness of ferrite film increases with the decrease of temperature transformation and with the increase of the time of heat treatment. Nevertheless, the thickness of thin ferrite film does not depend on time until $180 \mathrm{~s}$ at temperatures near $\mathrm{Ar}_{3}$ (950 $970^{\circ} \mathrm{C}$ ). Finally, this work contributes to reduce intergranular crack during hot rolling of nonoriented electrical steels.

\section{ACKNOWLEDGEMENTS}

The financial support from the Consejo Nacional de Ciencia y Tecnología (CONACYT) of México is gratefully recognized.

\section{REFERENCES}

[1] W.T. Lankford, Metall. Trans. 3 (1972) 1331-1357.

[2] A. Peece. J. Nutting and A. Hartley, J. Iron Steel Inst. 164 (1950) 37-43. 

IMPLICACIONES DEL CONTENIDO TOTAL DE SLICIO, ALUMINIO, CROMO Y FORMACIÓN DE PELICULAS DELGADAS DE FERRITA SOBRE LA BAJA DUCTILIDAD AALTA TEMPERATURA EN ACEROS ELÉCTRICOS NO ORIENTADOS

[3] T. Koand D. Hanson, J. Iron Sleel Inst. 164 (1950) 51-62.

[4] S. Y. Ogawa,T. B. King and N. J. Grant, Journal of Metals: Trans. Metall. Soc. AIME, 224 (1962) 112-123.

[5] R. A. Reynolds and W. J. McG. Tegart, J. Iron Steel Inst. 200 (1962) 1044-1059.

[6] G. A. Wilber, R. Batra, W. F. Savage and W. J. Childs, Metall. Trans. 6A (1975) 1727-1735.

[7] J. Bellot and M. Gantois, Trans. Iron Steel Inst. Jpn.18 (1978) 536-545.

[8] F. Weinberg, Metall. Trans. 10B (1979) 513-522.

[9] H. G. Suzuki, S. Nishimura and S. Yamaguchi, Trans. Iron Steel Inst. Jpn. 22 (1982)48-56.

[10] K. Yasumoto,Y. Maehara, S. Ura and Y. Ohmori, Mater. Sci. Technol. 1 (1985) 111-116.

[11] M. Tacikowski, G. A. Osinkolu and A. Kobylanski, Mater. Sci. Tech. 2 (1986) 154-158.

[12] C. Nagasaki. A. Aizawa and J. Kihara, Trans. Iron Steel Inst. Jpn. 27 (1987) 506-512.

[13] H. Kobayashi, ISIJ Int. 31 (1991) 268-273.

[14] Y. Maeharaand K. Kamei, ISIJ Int. 34 (1994) 843-848.

[15] C. Nagasak and J. Kihara, ISIJ Int. 39 (1999) 75-83.

[16] E. Gamsjager, M. Militzer, F. Fazeli J. Svoboda and F. D. Fischer, Comput. Mater. Sci. 37 (2006) 94-100.

[17] K. Yasumoto, Y. Maehara, S. Ura and Y. Ohmori, Mater. Sci. Technol. 1 (1985) 111-116.

[18] S. W. Lee, D. H. Seo and W. Y. Choo, J. Kor. Inst. Met. Mater. 36 (1998) 1966-1973.

[19] P. D. Hodgson, M. R. Hickson and R. K. Gibbs, Scr. Metall. Mater. 40 (1999) 1179-1184.

[20] M. Niikura, M. Fujioka, Y. Adachi, A. Matsukura, T. Yokota, Y. Shirota and Y. Hagiwara, J. Mater. Process. Techol. 117 (2001) 341-346.

[21] P. J. Hurley and P. D. Hodgson, Mater. Sci. Eng. A 302 (2001) 206-214.

[22] S. Lee, D. Kwon, Y. K. Lee and O. Kwon, Metall. Trans. A, 26 (1995) 1093-1100.

[23] K. Nagai, J. Mater. Process. Techol. 117 (2001) 329-332.

[24] Z. Q. Sun, W. Y. Yang, J. J. Qi and A. M. Hu, Mater. Sci. Eng. A, 334 (2002) 201-206.

[25] Y. D. Huang and L. Froyen, J. Mater. Process. Technol. 124 (2002) 216-226.
[26] E. Essadiqi and J. J. Jonas, Metall. Trans. A, 19A (1988) 417-426.

[27] B. Mintz, J. Lewis and J. J. Jonas, Mater. Sci. Tech. 13 (1997) 379-388.

[28] Y. Matsumura and H. Yada, Tetsu-to-Hagané. 69 (1983) 1460-1467.

[29] C. Ouchi and K. Matsumoto, Trans. Iron Steel Inst. Jpn. 22 (1982) 181-189.

[30] H. Yada, N. Matsuzu, K. Nakajima, K. Watanabe, and H. Tokita, Trans. Iron Steel Inst. Jpn. 23 (1983) 100-109.

[31] H. G. Suzuki, S. Nishimura and J. Imamura, Trans. Iron Steel Inst. Jpn. 24 (1984) 169-177.

[32] S. T. Hong, Proc. of the 2nd Workshop on The Development of High Performance Structural Steels for 21 th Century, Vol. 2 POSCO Pohang (1999) C-1.

[33] E. O. García-Sánchez, E. A. Treviño-Luna, A. Salinas-Rodríguez y L. A. Leduc-Lezama, Rev. Metal. Madrid. 43 (2007) 266-271.

[34] G. I. S. L. Cardoso, S. Yue, Proc. AIME Mech. 31 (1989) 585-589.

[35] J. Y. Fu, I. García, S. Pytel and A. J. De Ardo, Processing Microstructure and Properties of HSLA Steels. Metallurgical Society of AIME, Warrendale, PA. USA, 27, 1988, pp. 1811 1823.

[36] A. Cowley, R. Abushosha, B. Mintz, Mater. Sci. Techl. 14 (1998) 1145-1153.

[37] B. Mintz, R. Abushosha, and M. Shaker, Mater. Sci. Techl. 9 (1993) 907-914.

[38] H. Yada, C. M. Li and H. Yamagata, ISIJ Int., 40 (2000) 200-206.

[39] I. Tamura, H. Sekine, T. Tanaka, C. Ouchi, Journal of the Iron and Steel Institute, Butterworths, London, 1988, pp. 162-169.

[40] P. V. Morr, A. J. Bdttger and E. J. Mittemeijer, Journal of Thermal Analysis and Calorimetry. 64 (2001) 905-911.

[41] R. C. Reed and H. K. D. H. Bhadeshia, Mater. Sci. Tech. 8 (1992) 421-435.

[42] K. Ushioda, O. Akisue, K. Koyama, Y. T. Hayashida, Sheet Steels, R. Pradhan and I. Gupta (Eds.), 1992, pp. 261-286.

[43] E. O. García Sánchez. Thesis PhD, CINVESTAV Saltillo, México 2006. 